Annals of Tropical Research, 33(1): 85-100 (2011)

\title{
Production of Carbon Offsets Using Conservation Agriculture Practices
}

\author{
Jean-Francois Rochecouste and Paul Dargusch \\ School of Agricultural and Food Sciences, The University of Queensland, \\ Brisbane 4072, Australia
}

\begin{abstract}
This paper examines opportunities for the United Nations Framework Convention on Climate Change (UNFCCC) to consider financial mechanisms for the uptake of conservation agriculture (CA) practices in developing countries to reverse the loss of soil organic carbon. Conservation agriculture, commonly described as the reduction of tillage, maintaining soil cover and introducing crop rotations, is currently being promoted by the United Nations Food and Agriculture Organisation as the most sustainable form of farming into the future. It was found that the increasing uptake of CA practices by developed countries improved soil organic carbon benefit and reduced energy inputs. Furthermore industrial agriculture has evolved a range of new technologies that can be adapted in developing countries to improve food security, increase environmental benefits and provide carbon offsets. This is in line with the climate change mitigation strategy of putting atmospheric carbon back in the soil to increase soil organic carbon. It is also noted that recognising conservation agriculture methodologies in carbon offset schemes would require the development of alternative economic instruments specifically to support small landholder changes in farming practices such as exist for hydrological and biodiversity ecosystem services schemes. Some of the constraints for small landowners providing agricultural carbon offsets are investment capital and an established trading mechanism that recognises the inherent issues of agriculture. Adaptation of conservation agricultural practices from industrialised agriculture to developing countries is examined along with current offset schemes being proposed in developed countries. A review of the literature examines Payment for Ecosystem Services (PES) and suggests a number of methodologies for consideration as part of an offset market. It was found that the two main obstacles in market terms are the acceptance of a level of soil carbon sequestration that can be easily calculated and the degree of attached liability for farmers in selling the equivalent of a Certified Emission Reduction unit from a highly volatile system.
\end{abstract}

Keywords: payments for ecosystem services (PES), market instruments, soil organic carbon (SOC), climate change policy, greenhouse gas emissions, clean development mechanism (CDM), developing countries 


\section{INTRODUCTION}

The United Nations Food and Agriculture Organisation (FAO) describes the principles of conservation agriculture as minimal soil disturbance, permanent soil cover and crop rotations (FAO, 2011). Agriculturists in developed countries have long recognised the value of conservation agricultural practices in delivering greater production while reducing the adverse environmental impacts of traditional agriculture including emissions of carbon dioxide $\left(\mathrm{CO}_{2}\right)$ and nitrous oxide $\left(\mathrm{N}_{2} \mathrm{O}\right)$ (Allmaras and Dowdy, 1985; Hobbs, 2007; Martins et al., 2009). The supporting axiom of conservation agriculture is the development of stable, long-term soil health. In many established agricultural areas this requires reversing the loss of soil organic carbon resulting from conventional farming practices (Roldán et al., 2003; Govaerts et al., 2007). The adoption of conservation agriculture in developing countries can provide reductions of atmospheric $\mathrm{CO}_{2}$ emissions from reduced tillage, increases in soil organic carbon (SOC) on degraded land (Farage et al., 2007; Hernanz et al., 2009) and improved production through better water use efficiency and nutrient management (Gajri et al., 2002; FAO, 2011). Opportunities exist within the United Nations Framework Convention on Climate Change (UNFCCC) for agriculture to play a role based on the 2009 Copenhagen Accord where the text of agreement from agenda item 9, draft decision COP.15 states on page 2, section 3 - 'We agree that developed countries shall provide adequate, predictable and sustainable financial resources, technology and capacity-building to support the implementation of adaptation action in developing countries' (UNFCCC, 2009). In agricultural terms developed countries have the production technology capacity to support developing countries improve soil organic carbon levels to increase crop production and reduce greenhouse gas emissions.

Currently agricultural cropping is not extensively involved in soil carbon offset projects because of the variability of soils and the high cost of monitoring and verification of soil C stocks. The post-2012 climate policy framework holds the opportunity for the development of a carbon trading nexus for ecosystem services provided by the uptake of established conservation agricultural practices in developing countries (Antle and Stoorvogel, 2009). Such a trading mechanism would allow for the flow of financial resources from high greenhouse gas emitting countries to low emission developing countries, most of which are in tropical latitudes. The global benefit of conservation agriculture extends to improved food security and reduced water pollution coupled with soil carbon sequestration (Stocking, 2003; Gowing and Palmer, 2008). In designing payment for ecosystem services (PES) mechanisms it is necessary to understand both the 'potential' and 'limitations' of conservation agriculture operating in developing countries (Kassam et al., 2009).

The aims of the research reported here are to examine:

a) the value of conservation agriculture from an environmental perspective in balancing soil and atmospheric carbon, along with the available capacity to manage this by developing countries; 
b) the economic constraints in reversing the loss of soil organic carbon in food production;

c) mechanisms to manage the constraints and the relative benefits of applying these mechanisms in developing countries.

The method consists of a review of the literature on conservation agriculture, current trends in payment for ecosystem services and the development of carbon offset markets in developed countries.

\section{THE NATURE OF CONSERVATION AGRICULTURE AND THE BENEFITS TO SOIL HEALTH}

Conservation agriculture is underpinned by soil capacity to produce food crops without losing the basis of its fertility over time. Fertility can be maintained from increasing soil organic carbon by reducing tillage and increasing biomass input (Uri, 2000). In countries that have been practising some form of conservation agriculture, the targeted outcomes have not changed but the process of industrial agriculture has expanded to include practices beyond reduced tillage, stubble retention and crop rotation (Butler, 2008; Ashworth et al., 2010) as listed in Table 1. These practices are in fact processes consistently aimed at the goal of regaining soil structure, improving water-use efficiency and replacing the soil organic carbon lost from previous conventional tillage agriculture (Chan et al., 2003; Diels et al., 2004).

Table 1 shows the range of conservation agriculture practices used by farmers in developed countries including Australia, Canada and the USA, their general environmental benefits and their potential adaptability to farmers in developing countries. The assessment of whether to introduce change in practices should carefully consider the contextual needs of the agricultural regions before any attempts are made at transposing a new system to a region.

The value of conservation agriculture as a universal practice is that it is goaloriented rather than being process-driven. It focuses on soil health outcomes but is not prescriptive as to how that may be achieved. Farmers and agronomists in each agroclimatic zone may find their own local solutions to suit their own conditions, as farmers in Brazil, Canada and Australia have done. They can borrow ideas but develop only those parts that suit the context of their system. The adoption of conservation agriculture supports atmospheric $\mathrm{CO}_{2}$ reduction by increasing soil organic carbon (Johnson et al. 2007) and supports climate change adaptation by increasing food production efficiency in drier areas (World Bank 2010). The amount of carbon that can be sequestered varies widely, depending on soil types and climate (Lal, 2004; Johnson et al. 2007; Sanderman et al. 2009). This variation can create governance issues in determining if a farm has in fact removed an actual tonne of carbon from the atmosphere when selling an 'offset unit'. Nonetheless the imperative of improving global food security by financially supporting better agricultural practices for poorer landholders should allow some leeway in accepting an imperfect carbon market in developing countries. 
Table 1. Modern adaptations of conservation agriculture from high-input agriculture, their environmental impacts and potential adaptability to developing countries

\begin{tabular}{|c|c|c|}
\hline $\begin{array}{l}\text { Current conservation } \\
\text { farming practice in } \\
\text { developed countries } \\
\end{array}$ & $\begin{array}{l}\text { Associated environmental } \\
\text { benefit }\end{array}$ & $\begin{array}{l}\text { Adaptability of the practice } \\
\text { to developing countries }\end{array}$ \\
\hline $\begin{array}{l}\text { No-till to minimise soil } \\
\text { disturbance except at } \\
\text { planting (Ugalde et al., } \\
\text { 2007; Llewellyn et al., } \\
\text { 2009) }\end{array}$ & $\begin{array}{l}\text { Reduced loss of SOC and } \\
\text { soil erosion, increased water } \\
\text { use efficiency (WUE) and } \\
\text { reduced } \mathrm{CO}_{2} \text { emissions } \\
\text { (Bayer et al., 2001; Roldán } \\
\text { et al., 2003; Wang and Dalal, } \\
\text { 2006; Ashworth et al., 2010) }\end{array}$ & $\begin{array}{l}\text { Small no-till planters can } \\
\text { be adapted to small-scale } \\
\text { agriculture in developing } \\
\text { countries and a number of } \\
\text { small-scale machines are } \\
\text { being further developed } \\
\text { (Blackwell, 2006) }\end{array}$ \\
\hline $\begin{array}{l}\text { Crop stubble retention to } \\
\text { protect soil (Li et al., } \\
\text { 2001). Including } \\
\text { techniques for managing } \\
\text { crop stubble with planters } \\
\text { and preventing seasonal } \\
\text { weed and disease carry- } \\
\text { over. }\end{array}$ & $\begin{array}{l}\text { Higher SOC, reduced } \\
\text { erosion and run-off of } \\
\text { agrochemicals (Baker and } \\
\text { Mickelson 1994; Yadav et } \\
\text { al., 1994; Malinda 1995; Uri, } \\
\text { 2000) }\end{array}$ & $\begin{array}{l}\text { Stubble retention is well } \\
\text { established in Brazil } \\
\text { (Galdos et al., 2009; } \\
\text { Pinheiro et al., 2010), with } \\
\text { increasing use in India with } \\
\text { improved zero-till } \\
\text { machinery (Millham, 2006) } \\
\text { and potential use in Africa } \\
\text { (Gowing and Palmer, 2008; } \\
\text { Thomas, 2008) }\end{array}$ \\
\hline $\begin{array}{l}\text { Controlled traffic farming } \\
\text { to reduce soil compaction } \\
\text { (Tullberg et al., 2007) }\end{array}$ & $\begin{array}{l}\text { Higher SOC and WUE, and } \\
\text { reduced erosion and } \mathrm{CO}_{2} \\
\text { emissions (Li et al. 2001; } \\
\text { Batey, 2009; Tullberg, 2009) }\end{array}$ & $\begin{array}{l}\text { Adaptability is less of a } \\
\text { problem in low-input } \\
\text { cropping but a potential } \\
\text { future issue as } \\
\text { mechanisation increases }\end{array}$ \\
\hline $\begin{array}{l}\text { Precision agriculture } \\
\text { technologies for inter-row } \\
\text { seeding, variable rate } \\
\text { applications of fertiliser, } \\
\text { targeted spraying } \\
\text { operations and yield } \\
\text { mapping to monitor } \\
\text { performance }\end{array}$ & $\begin{array}{l}\text { Reduced } \mathrm{CO}_{2} \text { emissions, } \\
\text { reduced fertiliser and } \\
\text { associated } \mathrm{N}_{2} \mathrm{O} \text { emissions } \\
\text { (Butler, 2008; Mayfield and } \\
\text { Trengrove ,2009) }\end{array}$ & $\begin{array}{l}\text { Not suitable in areas } \\
\text { without GNSS reference } \\
\text { stations and the initial } \\
\text { investment would only be } \\
\text { affordable by large farms }\end{array}$ \\
\hline $\begin{array}{l}\text { Legume crop rotation to } \\
\text { increase soil nitrogen } \\
\text { (Giller, 2001) }\end{array}$ & $\begin{array}{l}\text { Higher SOC and reduced } \\
\text { nitrous oxide emissions } \\
\text { (Roldán et al., 2003; } \\
\text { Boddey, et al. 2010; Huth et } \\
\text { al., 2010) }\end{array}$ & $\begin{array}{l}\text { Well established in some } \\
\text { regions but requires } \\
\text { continuing agronomic } \\
\text { support (Adjei-Nsiah et al., } \\
\text { 2007) }\end{array}$ \\
\hline $\begin{array}{l}\text { Cover cropping using } \\
\text { green manure crops in } \\
\text { fallow periods (Uri, 2006) }\end{array}$ & $\begin{array}{l}\text { Higher SOC, carbon } \\
\text { sequestration and WUE } \\
\text { (Dabney et al., 2001; } \\
\text { Veenstra et al., 2007) }\end{array}$ & $\begin{array}{l}\text { Although of value to soil } \\
\text { health, there is a cost } \\
\text { impost because no income } \\
\text { is generated, so } \\
\text { affordability is a } \\
\text { constraining factor }\end{array}$ \\
\hline
\end{tabular}


Table 1. (Cont.)

\begin{tabular}{|c|c|c|}
\hline $\begin{array}{l}\text { Current conservation } \\
\text { farming practice in } \\
\text { developed countries }\end{array}$ & $\begin{array}{l}\text { Associated environmental } \\
\text { benefit }\end{array}$ & $\begin{array}{l}\text { Adaptability of the practice } \\
\text { to developing countries }\end{array}$ \\
\hline $\begin{array}{l}\text { Ecosystem services } \\
\text { including set aside } \\
\text { vegetation areas on farm } \\
\text { for biodiversity reserves } \\
\text { or water filtration } \\
\text { functions }\end{array}$ & $\begin{array}{l}\text { Increased biodiversity, } \\
\text { greater downstream water } \\
\text { quality, and carbon } \\
\text { sequestration in established } \\
\text { vegetation (Cocklin et al., } \\
\text { 2007) }\end{array}$ & $\begin{array}{l}\text { Mostly limited to forestry } \\
\text { (Mayrand and Paquin, } \\
\text { 2004), but is an emerging } \\
\text { option for agriculture (Antle } \\
\text { and Stoorvogel, 2009) }\end{array}$ \\
\hline $\begin{array}{l}\text { Application of composted } \\
\text { recycled organics from } \\
\text { city industries and } \\
\text { treatment plants }\end{array}$ & $\begin{array}{l}\text { Higher SOC and WUE, } \\
\text { avoided pollution (Gibson et } \\
\text { al., 2002) }\end{array}$ & $\begin{array}{l}\text { Usually well established but } \\
\text { attention to health and } \\
\text { heavy metal contamination } \\
\text { of bio-solids may be } \\
\text { required }\end{array}$ \\
\hline
\end{tabular}

SOC = soil organic carbon; WUE = water-use efficiency; OM = organic matter; GNSS = global navigation satellite system ${ }^{1}$

\section{CURRENT CONSTRAINTS IN RESTRUCTURING CROP PRODUCTION IN DEVELOPING COUNTRIES}

Agriculture has been predominantly an exploitive system of soil use, reducing inherent fertility over time (Lal, 2004); the market for the world's major crops maize, rice, soybeans and wheat - are commodity driven with many small producers accepting a competitive minimal price that reduces their ability to invest profits in long-term soil maintenance (Cudjoe et al., 2010; FAO, 2011). Food prices are becoming increasingly volatile, possibly as a result of changing opportunity costs to 'energy crops' (particularly maize for ethanol), alternative urban land use and speculation in the agricultural futures market (Gilbert, 2010). The degree of international competition has placed overall downward pressure on grain prices based on the available world stock. For example, commodity wheat prices from the Chicago Board of Trade December contracts ranged from 185 USD/tonne in 1980 to 175 USD/tonne in 2009, averaging $141 \mathrm{USD} /$ tonne over a 39 year period (Wheat Export Australia, 2009). Notwithstanding the fact that in some years the price of grain has been very high, reaching 320USD/tonne in 2007 when grain stocks reached a 39 year low. This provides an indication of the lack of upward pressure on grain prices in comparison to input costs of fertiliser and farm diesel based on finite energy resources, notably 'oil'. Although in food-supply terms this reducing gap between the price received by the farmer and his input costs is seen to reflect efficient markets in operation, there may be adverse long-term consequences emerging in soil maintenance

${ }^{1}$ GNSS is identical in meaning to GPS (Global Satellite Positioning). GPS is predominantly a US terminology, also known in other countries such as Australia, whereas GNSS is the accepted international term. 
capacity for food production. This trend of declining terms of trade for agriculture has decreased farmers' profit margins globally and means individual farmers potentially have a low capacity to finance long-term maintenance of their soil. In developing countries this is leading to decreased viability of productive land from erosion and loss of soil organic carbon (Cudjoe et al., 2010). Making changes to farming practices such as in Sub-Saharan Africa requires an up-front investment in stubble retention, green manure crops or recycled animal manure (Garcia-Torres et al., 2003; Knowler and Bradshaw, 2007; Ashworth et al., 2010). Most of the biomass produced by lowincome farmers has a competitive opportunity value for feeding livestock, fuel or construction of shelter for households (Giller et al., 2009). Financial limitations, including the lack of enabling education and appropriate technologies (Langyintuo et al., 2008) create a barrier to uptake of conservation agricultural practices (Lal, 2007a). Intervention by government is required to overcome social and economic constraints by providing basic institutional and legal infrastructure to protect the property rights of landowners and enforce the rule of law (Tabellini, 2005).

If the price obtained by a farmer for his produce is insufficient to support maintenance of their land, the farm might be regarded as financially unsustainable. In economic terms it could be said that the full contribution provided by the land's ecosystem services to the community in producing a food commodity has not been captured in valuation terms, in much the same way that Turner et al. (1994) described valuing environmental assets such as a woodland resource. If the market price for food does not meet the net cost of production, including maintenance of the soil's ecosystem services, then a consequence will be land degradation. At the macro level one might expect to see a continuing decline in the general health of soils with carbon mineralisation and loss of carbon from the soil pool (Lal, 2007b; Campbell, 2008). The use of new farming practices that increase soil carbon sequestration to remove carbon dioxide from the atmosphere is to some extent mitigating the loss of soil organic carbon from past agricultural practices. Many long-term subtropical farming areas in industrialised countries including Australia have been gradually investing in adopting practices to improve the long-term maintenance of the soil (Llewellyn et al., 2009). Many developing countries in tropical latitudes have limited resources to invest in changes of farm practices to maintain soil sustainability (Gowing and Palmer, 2008; FAO, 2011).

A change in a farming practice to improve soil health and increase crop yields must be supported with some initial investment in inputs including fertiliser and appropriate farm machinery. Rebuilding a soil's ecosystem to support agriculture is not a simple matter and may take many years of investment (Antle and Stoorvogel, 2009; Ashworth et al., 2010). Maize production in many parts of tropical Africa, for example, is still yielding below potential due to low genetic quality of varieties, inadequate weed control and insufficient fertiliser (Langyintuo et al., 2008, Sibuga 2009), problems which will not be solved by just changing farm practices. Growing maize successfully in poor soil will require an input of fertiliser for crop establishment and to produce sufficient biomass to create stubble cover. This input of nutrients in a system without soil cover will additionally support a large weed population, which needs to be managed without tillage. It takes a number of years of biomass accumulation to allow a reduction in herbicide and fertiliser inputs. 
Production of maize, rice and sugar in various agro-ecological zones can have unique requirements that demand local research (Diels et al., 2004; Metay et al., 2007; Lee et al., 2009; Pinheiro et al., 2010). However, regional agricultural research and extension can only go so far without appropriate economic signals that are consistent and reward practice change in line with the resources available to farmers. If farmers cannot obtain a price for their produce that will allow them to invest in maintaining their soil's health, can they be paid to adopt practices that reduce atmospheric carbon? Can the adoption of particular farming practices to offset emission change from voluntary units (VERs) to certified units (CERs)?

\section{MECHANISMS TO MANAGE CONSTRAINTS ON CONSERVATION AGRICULTURE}

The UNFCCC framework offers a potential opportunity for firms in industrialised nations to offset their greenhouse gas emissions by paying for sequestration credits from conservation agricultural practices in developing countries. The benefits that can be delivered to the global community apart from soil carbon sequestration are climate change adaptation in some areas and food security from more stable crop production. A constraint to the flow of investment in conservation agriculture is the rigorous nature of the Clean Development Mechanism (CDM) for monitoring and evaluating the degree of $\mathrm{CO}_{2}$ reductions offered as an offset (Locatelli and Pedroni, 2004). Given the high transaction costs associated with the CDM these project types do not easily suit small landholders who have to form large aggregations with stringent reporting requirements to gain sufficient economies of scale to make the activities costeffective. Soil organic carbon sequestration in agricultural systems is also prone to being quickly lost by changes in conditions (e.g. fire) or tillage practices (Buenemann et al., 2008), and this would create substantial contractual risk for small farmers. Adequate consideration also needs to be given to market distortion that can come from too simple a prescriptive system; a mechanism that rewards farmers for retaining crop stubble may affect the livestock industry that relies on stubble as feed. Conservation agriculture practices need to be developed in the social context of the region, allowing for its climate, with the goal of restoring soil health to a new equilibrium (Roose and Barthes, 2001).

A more flexible market mechanism could be developed to suit small-scale landholders in developing countries with the goal of managing climate change by improving soil health. The science on the benefits of conservation agriculture is well established (FAO, 2011); what is needed now is a willingness to test a range of market mechanisms that will engage and support farmers in developing countries to change practices and reassure investors that there is value in the process (Lipper, 2009). While food production will of necessity have some greenhouse gas emissions; it is possible to adopt emission reduction strategies that can be measured against a 'business as usual' scenario using new farming practices. Given the inherent variation of agricultural practices within and between countries, offset projects should consider accepting a wide range of practice changes providing that some basic level of necessary tests is met. Agricultural offset schemes already operating in developed countries such as the ones used by the Canadian province of Alberta have relatively 
straightforward audit requirements operated by certified agronomists (Climate Change Central, 2009). The Alberta scheme allows farmers to sell carbon offsets to industry via a state-operated market using reduced tillage as a practice criterion; farmers need to demonstrate verifiable reduced tillage and stubble retention. The degree of carbon that is sequestered by conservation agriculture for the soil type and emission reductions below the 'business as usual' baseline has an established agreed value, set by the provincial government based on local research, with allowance made for leakage and risk factors. The process is similar to that applied in a CDM project and the emission unit for the period is classified as permanent because it occurs during the designated period. The farmer is concerned only with verifying that the correct farming practice is adopted and not the carbon accounting. Although the fungibility of this offset unit is debatable, the adoption of similar schemes could deliver multiple benefits for agriculture in developing countries.

To determine an emission unit from practice change there is a need to invest in the establishment of localised 'business as usual' baselines which should include a crop yield function. The avoided emissions must relate to a production level in order to demonstrate production efficiency, so the farmer produces the same food value using fewer energy inputs. This linkage is important because maximising sustainability may not involve the same process as maximising productivity; small landholders can improve their personal productivity but may not be in relative terms maximise the production capacity for that area of land at that time. Investment in determining regional baselines for farm practices can create the potential for offset markets for measured practice change linked with increased production and increased soil organic carbon (Quick et al., 1984; Reicosky, 2002; Chivenge et al., 2007; Hobbs, 2007; Tullberg, 2008; Kassam et al., 2009). If the forward commitments to the UNFCCC beyond the 2012 reporting period of the Kyoto Protocol involve a framework for agriculture, there is substantial capacity to change agricultural practices in a way that would reduce emissions per tonne of production using conservation agriculture.

\section{RETHINKING CONSERVATION AGRICULTURE AS A PES SCHEME FOR SMALLHOLDERS IN DEVELOPING COUNTRIES}

In real terms the application of conservation agriculture practices in any jurisdiction cannot deliver a measurable and incontestable tonne of carbon dioxide removed from the atmosphere. The complex nature of ecosystems must be considered as delivering a different type of product that's not always readily characterised; it involves a multitude of sometimes intangible benefits to a community. Payments for ecosystem services (PES) involving the use of market-based instruments (MBIs) to support ecosystem services are relatively new in the international policy context (Whiten, 2005). The services that were initially identified for payments were provided by water utility companies made to landowners for maintained vegetation acting as hydrological services to provide clean water more cost effectively then an engineering solution (Smith et al., 2006). Biodiversity services were concerned with minimising anthropogenic impact on important ecosystems that held high biodiversity values. The benefit measurements and price consideration were only loosely connected and can 
vary from US\$45/ha/year for farmers in Costa Rica to US\$230/ha/year for farmers in France (Smith et al., 2006).

Experience from carbon sequestration in the biosphere as part of a PES scheme involving forests has a rigorous performance requirement incurring high transaction costs (Locatelli and Pedroni, 2004). When demand for carbon credits fell sharply during the peak of the global financial downturn in 2009, the European Climate Exchange spot price for carbon began to collapse, dropping from about €25/tonne $\mathrm{CO}_{2} \mathrm{e}$ in September 2008, to about $€ 15$ in September $2010^{2}$. For suppliers of carbon offsets in forestry projects, the associated high transaction costs made it difficult to prepare long-term projects that involve many stakeholders. Considering that these issues will also apply in the context of soil organic carbon storage, which has its own inherent volatility, it can be seen that a soil carbon sequestration project for carbon offsets is going to be challenged in terms of profitability and accuracy.

Developed countries including Canada, the USA and recently Australia have trading plans for carbon sequestration from agriculture. Australia has recently introduced the Carbon Farming Initiative 2011, a Bill which came into legislation in August 2011 to allow farmers to sell non-Kyoto compliant Australian Carbon Credit Units (ACCUs) for soil carbon storage, although a method on how a project will operate is not yet available.

In developing countries typically with small landholders, the process needs to operate at the simplest level, for example offering credit towards biomass input into the soil (straw or manure) based on a regionally accepted value per tonne of $\mathrm{CO}_{2}$ equivalent. Given that small landholders in developing countries are some of the poorest people on earth, they are unlikely to be able to supply the high level auditing process required by corporate investors. Table 2 presents the basic concepts of a number of PES mechanisms and lists some of the benefits and constraints of their operation. The issues highlighted provide insights to the development of pilot marketbased instruments that could operate in developing countries

Most current projects in the carbon market involving land use, aim for aboveground carbon sequestration via some form of tree management. Few projects have tackled soil as a carbon sink mainly due to the complexity of verifying the volume of storage and the long term liability risk attached for the farmer if that stored carbon should be lost (Sanderman et al., 2009). Climate change policy is missing an opportunity to achieve the mitigation benefits of replacing soil organic carbon from poor farming practices waiting for a perfect measurement framework for the carbon offset market. In physical terms the amount of carbon that can be sequestered by soils per hectare will only ever be small and the rate gradual over a long time-frame (Jarecki and Lal, 2003; Lal, 2004; Chivenge et al., 2007). In the context of the carbon market's financial paradigm of investors only paying the minimal market price for a verifiable tonne of $\mathrm{CO}_{2}$ removed; the direct value to farmers will at best be small given the added transaction costs.

\footnotetext{
${ }^{2}$ The European Climate Exchange EUA spot price on 13 September 2010. http://www.ecx.eu/
} 
Table 2: Payment for ecosystem services with alternative mechanisms that may suit a carbon offset project in developing countries

\begin{tabular}{|c|c|c|}
\hline Mechanism & $\begin{array}{l}\text { Operational benefits for } \\
\text { farmers }\end{array}$ & Constraints \\
\hline $\begin{array}{l}\text { Payment of a flat fee as } \$ / \text { ha } \\
\text { for carrying out a practice } \\
\text { (Lipper et al., 2009), e.g. } \\
\text { fertiliser management, } \\
\text { terracing, providing ground } \\
\text { cover, tree planting, } \\
\text { maintaining surface } \\
\text { vegetation. }\end{array}$ & $\begin{array}{l}\text { Simplicity, measurable } \\
\text { farm output, clear action } \\
\text { for farmers, equitable } \\
\text { from a farmer's } \\
\text { perspective. }\end{array}$ & $\begin{array}{l}\text { May not fit investor } \\
\text { criteria of ensuring an } \\
\text { certified tonne of } \mathrm{CO}_{2} \\
\text { offset, potentially } \\
\text { inefficient in market } \\
\text { terms, may not be } \\
\text { applicable across all } \\
\text { agricultural situations. }\end{array}$ \\
\hline $\begin{array}{l}\text { Payment per tonne of } \mathrm{CO}_{2} \\
\text { sequestered, e.g. small } \\
\text { community tree planting } \\
\text { measured plant growth } \\
\text { calculators. }\end{array}$ & $\begin{array}{l}\text { Supplying a tonne of } \\
\text { sequestered } \mathrm{CO}_{2} \text { is a } \\
\text { recognised international } \\
\text { service, farmers can seek } \\
\text { the best price from the } \\
\text { broader carbon offset } \\
\text { market. }\end{array}$ & $\begin{array}{l}\text { Limited to projects that } \\
\text { can accurately measure } \\
\mathrm{CO}_{2} \text { sequestration. } \\
\text { May require large areas to } \\
\text { be aggregated to supply a } \\
\text { workable volume of CER } \\
\text { to the market. Volatile } \\
\text { carbon markets against } \\
\text { investment in long term } \\
\text { projects. }\end{array}$ \\
\hline $\begin{array}{l}\text { Payment for land activities via } \\
\text { tenders or grants usually as a } \\
\text { one-off payment by corporate } \\
\text { and governments } \\
\text { (Cocklin et al., 2005). }\end{array}$ & $\begin{array}{l}\text { Farmers can evaluate the } \\
\text { cost benefit of a clearly } \\
\text { defined set of activities } \\
\text { within a time frame. } \\
\text { Measured output is the } \\
\text { responsibility of the buyer. }\end{array}$ & $\begin{array}{l}\text { Verification of } \mathrm{CO}_{2} \mathrm{e} \text { units } \\
\text { can be uncertain } \\
\text { depending on the buyer. } \\
\text { Ongoing maintenance is } \\
\text { uncertain, limited to } \\
\text { particular types of } \\
\text { projects. }\end{array}$ \\
\hline $\begin{array}{l}\text { Stewardship in the form of } \\
\text { continuing payment by } \\
\text { corporate or government. }\end{array}$ & $\begin{array}{l}\text { Provides resource } \\
\text { certainty over the long } \\
\text { term. }\end{array}$ & $\begin{array}{l}\text { Obtaining long-term } \\
\text { commitment from the } \\
\text { farmer, defining the long- } \\
\text { term maintenance } \\
\text { requirement of the project, } \\
\text { allowing for the cost of } \\
\text { inflation into the } \\
\text { agreement. }\end{array}$ \\
\hline
\end{tabular}

Antle et al. (2009), using case studies for agricultural soil carbon sequestration in Kenya, Peru and Senegal, outline the contract design problems and transaction cost barriers to uptake. Whilst the results achieved in mitigation terms are less than ideal, and may not fit the requirements of a CER, it is creating changes in farmer behaviour towards higher soil organic carbon. 


\section{CONCLUSION}

The value of conservation agriculture to improve soil health using a number of farm practices will reduce carbon emissions in comparison to traditional tillage agriculture. Improving soil health can also incorporate a number of ecosystem services of value to the global community. Humanity has been exploiting the benefits of soil organic carbon for decades in the form of low cost commodities and in so doing cannot rebalance the soil's credit system without some form of repayment. In both physical and financial terms it will take decades of amortised investment to redress the loss of soil organic carbon which is impoverishing cropping soils. There is a need to financially revalue the services offered by cropping soils to allow for long term maintenance of soil organic carbon. In this context the addition of a carbon market that can work in conjunction with agricultural aid programs using established agricultural research and development outputs would provide a long-term proactive process to support developing countries. Many aid programs already have agricultural technical capacity in place to support agriculture. In pragmatic terms, financing some simple practices in the productive tropical latitudes, such as reducing soil erosion and returning a net proportion of biomass, can bundle a number of issues, not only carbon sequestration, but climate change adaptation and food security. Achieving this requires recognition of the limitations imposed by transaction costs for small landholders, and structuring simpler models that may not perfectly account for every tonne of carbon but are nevertheless moving in the right direction.

\section{REFERENCES}

ADJEI-NSIAH, S., KUYPER, T.W., LEEUWIS, C., ABEKOE, M.K. and K.E. GILLER. 2007. Evaluating sustainable and profitable cropping sequences with cassava and four legume crops: Effects on soil fertility and maize yields in the forest/savannah transitional agro-ecological zone of Ghana. Field Crops Research. 103(2): 87-97.

ALLMARAS, R. and R. DOWDY. 1985. Conservation tillage systems and their adoption in the United States. Soil Tillage Research. 5(2): 197-222.

ANTLE, J.M. and J.J. STOORVOGEL. 2009. Payment for ecosystem services, poverty and sustainability: the case of agricultural soil carbon sequestration. In: Payment for Environmental Services in Agricultural Landscapes, L.S. Lipper, T. Sakuyama, R. Stringer and D. Zilberman (eds), FAO of the United Nations and Springer Science + Business Media, Springer, New York. pp. 133-161.

ASHWORTH, J., DESBIOLLES, J. and E. Tola. 2010. Disc seeding in zero-till farming systems: A review of technology and paddock issues. Western Australia No-till Farmers Association, Perth.

BAKER, J. and S. MICKELSON. 1994. Application technology and best management practices for minimising herbicide runoff. Weed Technology. 8(4): 862-869.

BATEY, T. 2009. Soil compaction and soil management: A review. Soil Use and Management. 25(4): 335-345.

BAYER, C., MARTIN-NETO, L., MIELNICZUK, J., PILLON, C.N. and L. SANGOI. 2001. Changes in soil organic matter fractions under subtropical no-till cropping systems. Soil Science Society of America Journal. 65(5): 1473-1478. 
BLACKWELL, J. 2006. Fine-tuning the Happy Seeder technology for adoption in Northwest India. Report to Australian Centre for International Agricultural Research, Canberra.

BODDEY, R.M., JANTALIA, C.P., CONCEICAO, P.C., ZANATTA, J.A., BAYER, C., MIELNICZUK, J., DIECKOW, J., DOS SANTOS, H.P., DENARDIN, J.E., AITA, C., GIACOMINI, S.J., ALVES, B.J.R. and S. URQUIAGA. 2010. Carbon accumulation at depth in Ferralsols under zero-till subtropical agriculture. Global Change Biology. 16(2): 784-795.

BUENEMANN, E.K., MARSCHNER, P., SMERNIK, R.J., CONYERS, M. and A.M. MCNEILL. 2008. Soil organic phosphorus and microbial community composition as affected by 26 years of different management strategies. Biology and Fertility of Soils. 44(5): 717-726.

BUTLER, G. (ed.) 2008. Conservation Agriculture: Moving Beyond Adoption. SANTFA, Clare, South Australia.

CAMPBELL, A. 2008. Managing Australia's soils: a policy discussion paper. National Commitee on Soil and Terrain, Queenbeyan, Australian Capital Territory.

CHAN, K.Y., HEENAN, D.P. and H.B. SO. 2003. Sequestration of carbon and changes in soil quality under conservation tillage on light-textured soils in Australia: a review. Australian Journal of Experimental Agriculture. 43(4): 325-334.

CHIVENGE, P.P., MURWIRA, H.K., GILLER, K.E., MAPFUMO, P. and J. SIX. 2007. Long-term impact of reduced tillage and residue management on soil carbon stabilization: implication for conservation agriculture on contrasting soils. Soil and Tillage Research. 94(2): 328-337.

CLIMATE CHANGE CENTRAL. 2009. Specified Gas Emitters Regulation: Quantification Protocol for Tillage System Management: version 1.3, February 2009. Climate Change Central, Edmonton.

COCKLIN, C., MAUTNER, N. and J. DIBDEN. 2007. Public policy, private landholders: perspectives on policy mechanisms for sustainable land management. Journal of Environmental Management. 85(4): 986-998.

CUDJOE, G., BREISINGER, C. and X.S. DIAO. 2010. Local impacts of a global crisis: Food price transmission, consumer welfare and poverty in Ghana. Food Policy. 35(4): 294-302.

DABNEY, S.M., DELGADO, J.A. and D.W. REEVES. 2001. Using winter cover crops to improve soil and water quality. Communications in Soil Science and Plant Analysis. 32(7): 1221-1250.

DIELS, J., VANLAUWE, B., VAN DER MEERSCH, M.K., SANGINGA, N. and R. MERCKX. 2004. Long-term soil organic carbon dynamics in a subhumid tropical climate: C-13 data in mixed C-3/C-4 cropping and modeling with ROTHC. Soil Biology and Biochemistry. 36(11): 1739-1750.

FARAGE, P.K., ARDÖ, J., OLSSON, L., RIENZI, E.A., BALL, A.S. and J.N. PRETTY. 2007. The potential for soil carbon sequestration in three tropical dryland farming systems of Africa and Latin America: a modelling approach. Soil and Tillage Research. 94(2): 457-472.

FAO (FOOD AND AGRICULTURE ORGANIZATION OF THE UNITED NATIONS). 2011. Save and Grow: a Policy Maker's Guide to the Sustainable Intensification of Smallholder Crop Production. FAO, Rome 2011. 
GAJRI, P.R., ARORA, V.K. and S.S. PRIHAR, 2002. Tillage for Sustainable Cropping. Food Products Press imprint of Haworth Press. New York.

GALDOS, M.V., CERRI, C.C. and C.E.P. CERRI. 2009. Soil carbon stocks under burned and unburned sugarcane in Brazil. Geoderma. 153(3-4): 347-352.

GARCIA-TORRES, L., BENITES, J., MARTINEZ-VILELA, A. and A. HOLGADOCABRERA. 2003. Conservation agriculture: Environment, Farmers Experiences, Innovations, Socio-economy Policy. Kluwer Academic Publishers, Boston.

GIBSON, T.S., CHAN, K.Y., SHARMA, G. and R. SHEARMAN. 2002. Soil Carbon Sequestration Utilising Recycled Organics: A review of the Scientific Literature. The Organic Waste Recycling Unit, Sydney.

GILBERT, C.L. 2010. How to understand high food prices. Journal of Agricultural Economics. 61(2): 398-425.

GILLER, K. 2001. Nitrogen Fixation in Tropical Cropping Systems 2nd Edition. CABI Publishing, Wallingford, England.

GILLER, K., WITTER, E. CORBEELS, M. and P. TITTONELL. 2009. Conservation agriculture and smallholder farming in Africa: the heretics' view. Field Crops Research. 114(1): 23-34.

GOVAERTS, B., MEZZALAMA, M., UNNO, Y., SAYRE, K.D., LUNA-GUIDO, M., VANHERCK, K., DENDOOVEN, L. and J. DECKERS. 2007. Influence of tillage, residue management, and crop rotation on soil microbial biomass and catabolic diversity. Applied Soil Ecology. 37(1-2): 18-30.

GOWING, J.W. and M. PALMER. 2008. Sustainable agricultural development in subSaharan Africa: the case for a paradigm shift in land husbandry. Soil Use and Management. 24(1): 92-99.

HERNANZ, J.L., SÁNCHEZ-GIRÓN, V. and L. NAVARRETE. 2009. Soil carbon sequestration and stratification in a cereal/leguminous crop rotation with three tillage systems in semiarid conditions. Agriculture, Ecosystems and Environment. 133(1-2): 114-122.

HOBBS, P.R. 2007. Conservation agriculture: what is it and why is it important for future sustainable food production? Journal of Agricultural Science. 145(2): 127-137.

HUTH, N.I., THORBURN, P.J., RADFORD, B.J. and C.M. THORNTON. 2010. Impacts of fertilisers and legumes on $\mathrm{N} 2 \mathrm{O}$ and $\mathrm{CO} 2$ emissions from soils in subtropical agricultural systems: a simulation study. Agriculture, Ecosystems and Environment. 136(3-4): 351-357.

JARECKI, M.K. and R. LAL. 2003. Crop management for soil carbon sequestration. Critical Reviews in Plant Sciences. 22(5): 471-502.

JOHNSON, J. M.-F., FRANZLUEBBERS, A.J., WEYERS, S.L. and D.C. REICOSKY. 2007. Agricultural opportunities to mitigate greenhouse gas emissions. Environmental Pollution. 150(2007): 107-124.

KASSAM, A., FRIEDRICH, T., SHAXSON, F., and J. PRETTY. 2009. The spread of conservation agriculture: justification, sustainability and uptake. International Journal of Agricultural Sustainability. 7(4): 292-320.

KNOWLER, D. and B. BRADSHAW. 2007. Farmers' adoption of conservation agriculture: a review and synthesis of recent research. Food Policy. 32(1): 25-48.

LAL, R. 2004. Soil carbon sequestration to mitigate climate change. Geoderma. 123(1-2): $1-22$. 
LAL, R. 2007a. Constraints to adopting no-till farming in developing countries. Soil and Tillage Research. 94(1): 1-3.

LAL, R. 2007b. World soils and global issues. Soil and Tillage Research. 97(1): 1-4.

LANGYINTUO, A.S., MWANGI, W., DIALLO, A.O., MACROBERT, J., DIXON, J. and M. BÄNZIGER. 2008. An analysis of the bottlenecks affecting the production and deployment of maize seed in eastern and southern Africa. International Maize and Wheat Improvement Centre (CYMMIT). Harare, Zimbabwe.

LEE, S.B., LEE, C.H., JUNG, K.Y., DO PARK, K., LEE, D. and P.J. KIM. 2009. Changes of soil organic carbon and its fractions in relation to soil physical properties in a long-term fertilized paddy. Soil and Tillage Research, 104(2):227-232.

LI, Y.X., TULLBERG, J.N. and D.M. FREEBAIRN. 2001. Traffic and residue cover effects on infiltration. Australian Journal of Soil Research, 39(2): 239-247.

LIPPER, L.S., STRINGER, R. and ZILBERMAN, D. (eds.) 2009. Payment for Environmental Services in Agricultural Landscapes: Economic Policies and Poverty Reduction in Developing Countries. Natural Resource Management and Policy, FAO and Springer Science, New York and London.

LLEWELLYN, R., DEMDEN, F. and GOBBETT, D. 2009. Adoption of no-till and conservation farming practices in Australian grain growing regions: current status and trends. CSIRO, Glen Osmond, South Australia.

LOCATELLI, B. and L. PEDRONI. 2004. Accounting methods for carbon credits: impacts on the minimum area of forestry projects under the Clean Development Mechanism. Climate Policy. 4(2): 193-204.

MALINDA, D.K. 1995. Factors in conservation farming that reduce erosion. Australian Journal of Experimental Agriculture. 35(7): 969-978.

MARTINS, M.D., CORA, J.E., JORGE, R.F. and A.V. MARCELO. 2009. Crop type influences soil aggregation and organic matter under no-tillage.Soil andTillage Research. 104(1): 22-29.

MAYFIELD, A.H. and S.P. TRENGROVE. 2009. Grain yield and protein responses in wheat using the $\mathrm{N}$-Sensor for variable rate $\mathrm{N}$ application. Crop and Pasture Science. 60(9): 818-823.

MAYRAND, K. and M. PAQUIN. 2004. Payments for Environmental Services: A survey and Assessment of Current Schemes. Unisfera International Centre, Montreal.

METAY, A., MOREIRA, J.A.A., BERNOUX, M., BOYER, T., DOUZET, J.M., FEIGL, B., FELLER, C., MARAUX, F., OLIVER, R. and E. SCOPEL. 2007. Storage and forms of organic carbon in a no-tillage under cover crops system on clayey Oxisol in dryland rice production (Cerrados, Brazil). Soil and Tillage Research. 94(1): 122-132.

MILHAM, N. 2010. Industry and Investment NSW for Australian Centre for International Agricultural Research, project document CSE/2006/132, November 2010. Policy instrument to adopt air pollution issues in agriculture: Implications for Happy Seeder technology adoption in India. Available at http://aciar.gov.au/project/CSE/2006/132. 18 February 2011

PINHEIRO, E.F.M., LIMA, E., CEDDIA, M.B., URQUIAGA, S., ALVES, B.J.R. and soil carbon and nitrogen stocks on a sugarcane plantation in the Brazilian Atlantic forest region. Plant and Soil. 333(1-2): 71-80. 
QUICK, G.R., ANDREWS, A.S. and D.C. ERBACH. 1984. Oportunities to Reduce Energy Consumption in Tillage Operations in Australia. Agriculture Engineering Branch, Department of Agriculture, New South Wales, Dept. of Resources and Energy, Canberra, ACT.

REICOSKY, D.C. (ed.) 2002. Tillage and Gas Exchange, Encyclopedia of Soil Science, Taylor and Francis, Boca Raton.

ROLDÁN, A, CARAVACA, F., HERNÁNDEZ, M.T., GARCÍA, C., SÁNCHEZ-BRITO, C., VELÁSQUEZ, M. and M. TISCAREÑO. 2003. No-tillage, crop residue additions, and legume cover cropping effects on soil quality characteristics under maize in Patzcuaro watershed (Mexico). Soil and Tillage Research. 72(1): 65-73.

ROOSE, E. and B. BARTHES. 2001. Organic matter management for soil conservation and productivity restoration in Africa: a contribution from Francophone research. Nutrient Cycling in Agroecosystems. 61(1-2): 159-170.

SANDERMAN, J., FARQUHARSON, R. and J. BALDOCK. 2009. Soil Carbon Sequestration Potential: A Review for Australian Agriculture. A report for Department of Climate Change and Energy Efficiency. Commonwealth Scientific Research Industry Organisation (CSIRO), Canberra, Australia.

SIBUGA, K.P. 2009. Strategies for weed control to increase sustainable crop production in Africa. African Crop Science Conference Proceedings. Vol. 9: pp. 651-657. African Crop Science Society, Uganda.

SMITH, M., DE GROOT, D. and G. BERGKAMP. 2006. PAY: Establishing Payments for Watershed Services. World Conservation Union (IUCN) Accessed 13 September 2010. http://cmsdata.iucn.org/downloads/pay_1.pdf.

STAGER, J. 2010. Economic valuation of climate change adaptation in developing countries. In: K. Limburg and R. Costanza (eds), Ecological Economics Reviews. Vol. 1185: pp 150-163. Wyley-Blackwell, Malden.

STOCKING, M.A. 2003. Tropical soils and food security: the next 50 years. Science. 302: 1356-1359.

TABELLINI, G. 2005. The role of the state in economic development. Kyklos. 58(2): 283303.

THOMASM, R.J. 2008. Opportunities to reduce the vulnerability of dryland farmers in Central and West Asia and North Africa to climate change. Agriculture, Ecosystems and Environment. 126(1-2): 36-45.

TULLBERG, J. 2008. Tillage, Traffic and Sustainability - a Challenge for ISTRO (keynote presentation). ISTRO-INFO, International Soil Tillage Research Organization, 2009. Izmir, Turkey.

TUlLBERG, J. 2009. CTF and Climate Change. Paper presented to 6th Australian Controlled Traffic Farming Conference, Dubbo, NSW, 12-14th August 2008. http://www.actfa.net/further_reading/index.html. Accessed 19 October 2011.

TULLBERG, J., YULE, D. and D. MCGARRY. 2007. Control traffic farming; from research to adoption in Australia. Soil and Tillage Research. 97(2): 272-281.

TURNER, R., PEARCE, P. and I. BATEMAN. 1994. Valuing concern for nature. In: Environmental Economics: an Elementary Introduction. Harvester Wheatsheaf, Hemel Hemstead. pp.108-127. 
UNFCCC (UNITED NATIONS FRAMEWORKS ON CLIMATE CHANGE CONVENTION). 2009. Decisions adopted by the Conference of the Parties. Report of the Conference of the Parties on its fifteenth session, held in Copenhagen from 7 to 19 December 2009, Copenhagen.

URI, N. 2000. Conservation practices in US agriculture and their impact on carbon sequestration. Environmental Monitoring and Assessment. 70(3): 323-344.

URI, N. 2006. Agriculture and the Environment, Novinka, New York.

VEENSTRA, J.J., HOWARTH, W.R. and J.P. MITCHELL. 2007. Tillage and cover cropping effects on aggregate-protected carbon in cotton and tomato. Soil Science Society of America Journal. 71(2): 362-371.

WANG, W.J. and R.C. DALAL. 2006. Carbon inventory for a cereal cropping system under contrasting tillage, nitrogen fertilisation and stubble management practices. Soil and Tillage Research. 91(1-2): 68-74.

WHITTEN, S. and SHELTON, D. 2005, Market for Ecosystem Services in Australia: practical design and case studies. CSIRO Sustainable Ecosystems, www.cifor.cgiar.org/pes/publications/pdf_files/Whitten-Australia.pdf. Accessed 15 June 2010.

WORLD BANK. 2010. World Development Report 2010: Development and Climate Change. World Bank, Washington DC.

WHEAT EXPORT AUSTRALIA. 2009. World Wheat Trends and the Effect on Australian Prices. Wheat Export Australia established 2008. Australian Government, Canberra. http://www.wea.gov.au /Archived/Statistics/Default.htm. Accessed 14 July 2010.

YADAV, R.L., PRASAD, S.R., SINGH, R. and V.K. SRIVASTAVA. 1994. Recycling sugarcane trash to conserve soil organic-carbon for sustaining yields of successive ratoon crops in sugarcane. Bioresource Technology. 49(3): 231-235. 